\title{
Adoptive cell therapy in combination with checkpoint inhibitors in ovarian cancer
}

\author{
Anders Handrup Kverneland ${ }^{1, *}$, Magnus Pedersen ${ }^{1, *}$, Marie Christine Wulff \\ Westergaard ${ }^{1}$, Morten Nielsen ${ }^{1}$, Troels Holz Borch ${ }^{1}$, Lars Rønn Olsen ${ }^{2,3}$, Gitte \\ Aasbjerg ${ }^{2}$, Saskia J. Santegoets ${ }^{4}$, Sjoerd H. van der Burg ${ }^{4}$, Katy Milne ${ }^{5}$, Brad H. \\ Nelson $^{5,6}$, Özcan Met ${ }^{1}$, Marco Donia ${ }^{1}$ and Inge Marie Svane ${ }^{1}$ \\ ${ }^{1}$ National Center for Cancer Immune Therapy, Department of Oncology, Copenhagen University Hospital, Herlev, Denmark \\ ${ }^{2}$ Section for Bioinformatics, DTU Health Technology, Technical University of Denmark, Kongens Lyngby, Denmark \\ ${ }^{3}$ Center for Genomic Medicine, Copenhagen University Hospital, Copenhagen, Denmark \\ ${ }^{4}$ Department of Medical Oncology, Oncode Institute, Leiden University Medical Center, Leiden, The Netherlands \\ ${ }^{5}$ Deeley Research Centre, BC Cancer, Victoria, Canada \\ ${ }^{6}$ Department of Medical Genetics, University of British Columbia, Vancouver, Canada \\ *These authors contributed equally to this work
}

Correspondence to: Inge Marie Svane, email: inge.marie.svane@regionh.dk

Keywords: adoptive cell therapy; tumor-infiltrating lymphocytes; ovarian cancer; combinational immune therapy; checkpoint inihibors

Received: March 27, $2020 \quad$ Accepted: April 27, $2020 \quad$ Published: June 02, 2020

Copyright: Kverneland et al. This is an open-access article distributed under the terms of the Creative Commons Attribution License 3.0 (CC BY 3.0), which permits unrestricted use, distribution, and reproduction in any medium, provided the original author and source are credited.

\section{ABSTRACT}

Immune therapy is a promising field within oncology but has been unsuccessful in ovarian cancer $(\mathrm{OC})$. Still, there is rationale and evidence supporting immune therapy in OC. We investigated the potential for adoptive cell therapy (ACT) from in vitro expanded tumor-infiltrating lymphocytes (TILs) in combination with checkpoint inhibitors (ICI) and conducted immunological testing of ex vivo expanded TILs (REP-TILs).

Six patients with late-stage metastatic high-grade serous OC were treated with immune therapy consisting of ipilimumab followed by surgery to obtain TILs and infusion of REP-TILs, low-dose IL-2 and nivolumab.

One patient achieved a partial response and 5 others experienced disease stabilization for up to 12 months. Analysis of the REP-TILs with flow- and masscytometry show primarily activated and differentiated effector memory $\mathrm{T}$ cells. REP-TILs showed in vitro reactivity and expression of inhibitory receptors, such as LAG-3 and PD-1. Furthermore, our data indicate that addition of ipilimumab therapy improves the $T$ cell fold expansion during production, increase the level of CD8 T cell tumor reactivity, and favorably affect the $T$ cell phenotype.

We show that the combination of ICI and ACT is feasible and safe. With one partial response and one long-lasting SD, we demonstrated the potential of ACT in OC.

\section{INTRODUCTION}

Ovarian cancers are frequently infiltrated with immune cells. $\mathrm{T}$ cell infiltration and, especially the number of CD8 $\mathrm{T}$ cells, is correlated to longer survival in ovarian cancer patients [1-3]. While ovarian cancer is characterized by a low to intermediate mutational burden
$[4,5]$, a feature generally considered as an indication of low immunogenicity and responsiveness to immune therapy [6], we and others have demonstrated tumor reactivity amongst TILs [7] and peripheral blood lymphocytes [8] in ovarian cancer patients suggesting a potential for immune therapy.

Immune checkpoint inhibitors (ICI) has altered the landscape of cancer therapy in the recent decade, building 
a new independent pillar of immunotherapy. Several clinical trials have tested ICI in ovarian cancer patients but so far with very modest results. A study in 20 ovarian cancer patients showed an overall response rate (ORR) of $15 \%$ with the anti-PD-1 antibody nivolumab [9], but in a recently published, and much larger trial of 294 patients, the ORR was only $8 \%$ with the anti-PD-1 antibody pembrolizumab [10]. This is low when compared with the response rates of up to $37 \%$ in melanoma and $19 \%$ in NSCLC [11-13]. The anti-CTLA4 antibody ipilimumab has also been tested in ovarian cancer patients, claiming an ORR of $10.3 \%$ in a still unpublished trial (NCT01611558).

Adoptive cell therapy (ACT) using ex vivo expanded tumor-infiltrating lymphocytes (TILs) is an immune therapy modality that has been successfully pioneered within malignant melanoma in the 1980s and -90s. ACT has early on been tested in ovarian cancer patients with promising results in both the adjuvant [14] and metastatic setting [15]. Concomitantly, smaller phase I and II trials for other cancer diagnoses have confirmed clinical efficacy outside malignant melanoma $[16,17]$. We recently published results from a small ACT pilot trial in ovarian cancer demonstrating feasibility but with no patients achieving objective responses [18]. Data from this trial indicated that the infused TILs had a high expression of the immune regulatory markers LAG-3 and PD-1.

The combination of different immune therapies is a natural next step and a promising field within oncology. An obvious and FDA approved example is the combination of nivolumab and ipilimumab that has shown a significantly increased clinical efficacy at the price of increased toxicity [19]. Ipilimumab is believed to prime and activate $\mathrm{T}$ cells early in the immune response [20] while the anti-PD-1 antibodies block PD-1 on already activated $T$ cells which are directly inhibited by PD-L1 expression of tumor cells [21]. Mouse studies show that blockade of the CTLA-4 and PD-1 receptors synergistically induce CD4 and CD8 T cell numbers in the tumor microenvironment (TME) [22-24]. These findings indicate that checkpoint inhibition may be beneficial in the ACT setting and several clinical trials combining ACT with either CTLA-4 or PD-1 blockade are underway (NCT02027935, NCT03296137, NCT03638375, NCT03645928, NCT01993719). Here we report the clinical outcome of combining ACT with both CTLA-4 and PD-1 blockade in ovarian cancer patients.

\section{RESULTS}

\section{Study population}

Between 2016 and 2017, seven patients with latestage and platinum-resistant high-grade serous ovarian cancer were recruited and underwent surgical tumor removal after ipilimumab infusion. One patient (\#5) was discontinued shortly after surgery due to rapid cancer disease progression and associated clinical deterioration. Six patients were treated with ex vivo expanded T cells (REP-TILs). The baseline patient characteristics are listed in Table 1.

\section{Feasibility and safety}

All patients received ipilimumab prior to tumor removal. Tumor harvest and ex vivo expansion of TILs were successful in all patients. One patient (\#6) could not undergo surgery and instead a double liver biopsy ( $2 \mathrm{~mm}$ ) was performed. Four patients underwent laparoscopic surgery to resect intraperitoneal metastases, and one patient had a lung metastasis removed. The median expansion time before rapid expansion protocol (REP) was 25 days (Range: 18-42 days). The therapy and expansion data are listed in Table 2.

Four patients received all Interleukin-2 (IL-2) doses (median: 14; range: 4-14) following the $\mathrm{T}$ cells and 3 patients received all 4 doses of nivolumab (median: 3.5 ; range: $1-4)$. In two patients, IL-2 therapy was prematurely discontinued due to respiratory toxicity (\#3) and dizziness (\#4). In three patients, nivolumab was prematurely discontinued due to patient's wish (\#4) and general deterioration in clinical condition (\#3 and \#6). The median admission time was 20.5 days (Range: 16-31 days).

Overall the treatment was tolerated with manageable and expected toxicities associated with $\mathrm{T}$ cell therapy including conditioning chemotherapy [25-28]. All grade 3-4 adverse events (AEs) are listed in Table 3. Most adverse events occurred during hospitalization for chemotherapy and $\mathrm{T}$ cell infusion. The median length of neutropenia was 5.5 days (range: 5-9 days) and all patients required either blood- or platelet transfusions. The infusion of autologous $\mathrm{T}$ cells was well tolerated. The most common adverse events were fever, chills and dyspnea. One patient (\#2) experienced severe respiratory deficiency managed at the intensive care unit. This patient had severe bilateral pleuritic fluid before $\mathrm{T}$ cell infusion that was deemed undrainable due to fluid compartmentalization.

The low-dose IL-2 regime was also generally well tolerated. The primary adverse events were fever, fatigue, dyspnea, nausea and vomiting. Two patients experienced immune-related adverse events (IrAEs) following the ICI treatment, which are attributed to these drugs. One patient (\#7) developed grade 3 colitis following the single dose ipilimumab, and T cell therapy had to be postponed until completion of prednisolone therapy.

\section{Clinical efficacy}

The best overall tumor response (BOR) comprised 1 partial response (PR) in patient \#1 and stable disease (SD) in the remaining 5 patients, whereof patient \#3 had an unconfirmed PR. Tumor regression was achieved in all patients (8-35\% size decrease in target lesions) early 
Table 1: Baseline patient characteristics

\begin{tabular}{|c|c|c|c|c|c|}
\hline ID & Age & Histology & Sites of disease & Prior systemic treatment & Prior lines \\
\hline 1 & 51 & $\begin{array}{c}\text { Serous } \\
\text { adenocarcinoma }\end{array}$ & $\begin{array}{l}\text { Peritoneum, vagina, } \\
\text { lymph nodes }\end{array}$ & $\begin{array}{c}\text { Carboplatin/paclitaxel, doxorubicin, } \\
\text { paclitaxel/bevacizumab, tisotumab vedotin }\end{array}$ & 4 \\
\hline 2 & 52 & $\begin{array}{l}\text { Serous } \\
\text { adenocarcinoma }\end{array}$ & $\begin{array}{l}\text { Peritoneum, lymph } \\
\text { nodes }\end{array}$ & $\begin{array}{c}\text { Carboplatin/paclitaxel, carboplatin/ } \\
\text { doxorubicin/bevacizumab, carboplatin/ } \\
\text { gemcitabin, topotecan }\end{array}$ & 4 \\
\hline 3 & 63 & $\begin{array}{l}\text { Serous } \\
\text { adenocarcinoma }\end{array}$ & $\begin{array}{l}\text { Peritoneum, lung, } \\
\text { pleura, lymph nodes, }\end{array}$ & $\begin{array}{c}\text { Carboplatin/paclitaxel, carboplatin/ } \\
\text { paclitaxel/bevacizumab, doxorubicin, } \\
\text { cabazitaxel, topotecan }\end{array}$ & 4 \\
\hline 4 & 60 & $\begin{array}{l}\text { Serous } \\
\text { adenocarcinoma }\end{array}$ & $\begin{array}{l}\text { Peritoneum, lymph } \\
\text { nodes }\end{array}$ & $\begin{array}{l}\text { Carboplatin/paclitaxel, carboplatin/ } \\
\text { paclitaxel/bevacizumab, doxorubicin, } \\
\text { paclitaxel, gemcitabin, trabectidin, } \\
\text { tisotumab vedotin }\end{array}$ & 7 \\
\hline 6 & 49 & $\begin{array}{l}\text { Serous } \\
\text { adenocarcinoma }\end{array}$ & $\begin{array}{l}\text { Peritoneum, lung, } \\
\text { liver, lymph nodes }\end{array}$ & $\begin{array}{l}\text { carboplatin/paclitaxel/bevacizumab, } \\
\text { doxorubicin, paclitaxel, topotecan }\end{array}$ & 4 \\
\hline 7 & 54 & $\begin{array}{l}\text { Serous } \\
\text { adenocarcinoma }\end{array}$ & $\begin{array}{l}\text { Peritoneum, lymph } \\
\text { nodes }\end{array}$ & $\begin{array}{l}\text { Carboplatin/paclitaxel, bevacizumab/ } \\
\text { caelyx, trabectidin }\end{array}$ & 3 \\
\hline
\end{tabular}

Table 2: Summary of expanded TILs (REP TILs), therapy and clinical response

\begin{tabular}{lccccccccccccc}
\hline ID & $\begin{array}{c}\text { Metastasis } \\
\text { location }\end{array}$ & $\begin{array}{c}\text { Exp. } \\
\text { time } \\
\text { (days) }\end{array}$ & $\begin{array}{c}\text { Surgery } \\
\text { to ACT } \\
\text { (days) }\end{array}$ & $\begin{array}{c}\text { Infused } \\
\text { cells } \\
(\mathbf{1 0 e 9 )}\end{array}$ & $\begin{array}{c}\text { Fold } \\
\mathbf{e x p}\end{array}$ & $\begin{array}{c}\text { CD3 } \\
\mathbf{( \% )}\end{array}$ & $\begin{array}{c}\text { CD4 } \\
\mathbf{( \% )}\end{array}$ & $\begin{array}{c}\text { CD8 } \\
\mathbf{( \% )}\end{array}$ & $\begin{array}{c}\text { IL-2 } \\
\text { doses }\end{array}$ & $\begin{array}{c}\text { Nivo- } \\
\text { lumab } \\
\text { doses }\end{array}$ & $\begin{array}{c}\text { BOR } \\
\text { BOS }\end{array}$ & $\begin{array}{c}\text { PFS } \\
(\mathbf{d a y s})\end{array}$ & $\begin{array}{c}\text { OS } \\
(\mathbf{d a y s})\end{array}$ \\
\hline 1 & Vagina & 18 & 34 & 107 & 5360 & 99.7 & 26.4 & 70.2 & 14 & 4 & PR & 99 & 685 \\
2 & Peritoneum & 42 & 65 & 21.9 & 1441 & 98.6 & 45.8 & 42.5 & 14 & 4 & SD & 342 & 489 \\
3 & Both ovaries & 21 & 58 & 93.9 & 4680 & 99.5 & 36.1 & 58.0 & 4 & 1 & SD & 86 & 214 \\
4 & Peritoneum & 25 & 62 & 75.0 & 3790 & 99.5 & 96.2 & 3.1 & 11 & 3 & SD & 84 & 280 \\
6 & Liver & 27 & 50 & 98.4 & 4920 & 93.6 & 7.8 & 88.5 & 14 & 2 & SD & 144 & 144 \\
7 & Peritoneum & 28 & 93 & 54.4 & 2720 & 99.1 & 73.0 & 20.9 & 14 & 4 & SD & 86 & 136 \\
Median & & 25 & 60 & 84.7 & 4235 & 99.3 & 41.0 & 50.2 & 14 & 3.5 & & 86 & 214 \\
\hline
\end{tabular}

after the $\mathrm{T}$ cell infusion with a median PFS of 86 days. At 12 weeks, 4 out of 6 patients had progressive disease (PD). One patient (\#2) had long-lasting SD for almost a year following the therapy. In general, serum levels of CA-125 correlated with tumor response on imaging. The clinical efficacy is shown in Figure 1.

\section{Phenotypic characterization of expanded TILs}

The phenotype of REP-TILs was characterized with flow- and mass cytometry. The infused cells were almost exclusively $\mathrm{T}$ cells with a median of $99.3 \%$ (range: 93.6-99.7\%) of live cells. In 3 patients CD8 T cells were the dominant subtype, including the two patients with objective responses, while CD4 T cells were dominant in the others, including the patient with long-lasting SD as listed in Table 2.

The REP TILs were almost exclusively effector memory (EM; CD45RA-CCR7-) T cells and had an overall negligible CD45RA expression. Both CD4 and CD8 T cell subsets were primarily CD27-,
CD28- and CD69+ which generally are considered marks of activation and differentiation. In contrast, the CD28 expression on CD4 $\mathrm{T}$ cells (median of $60.3 \%$ ) together with a low CD57 expression (CD4 median: 6,1\%; CD8 median: 1.8\%) indicated less differentiation. The expression of the immune regulatory checkpoints BTLA, PD-1, and especially LAG-3, was high, respectively $49.5 \%, 13.5 \%$ and $43.6 \%$ in CD4 T cells and $34.8 \%, 29 \%$ and $94.1 \%$ in CD8. Thus, the CD8 T cells were generally more activated and differentiated than the CD4 T cells and expressed more LAG-3 and PD-1. All results are shown in Figure 2.

Mass cytometry and clustering analyses were performed on REP-TILs from this and another clinical pilot trial, in which no ipilimumab treatment before surgery was used, resulting in $n=12$ samples, which allowed better clustering of $\mathrm{T}$ cell subsets. As shown in Figure 3 and Supplementary Table 3, we found $8 \mathrm{~T}$ cell clusters based on the expression of the eight lineage markers, all of which expressed HLA-DR. The infused T cells were primarily CD4 and CD8 EM T cells with 
Table 3: Safety and toxicity. List of grade 3 and 4 adverse events related to study drugs (CTCAE 4.0)

\begin{tabular}{|c|c|c|}
\hline Therapy & Adverse event (Grade 3-4) & $n$ \\
\hline \multirow[t]{11}{*}{ Chemotherapy } & Performance status 3-4 & 3 \\
\hline & Fatigue & 3 \\
\hline & Nausea & 1 \\
\hline & Vomiting & 1 \\
\hline & Diarrhea & 1 \\
\hline & Hyponatremia & 3 \\
\hline & Infection & 2 \\
\hline & Neutropenia & 6 \\
\hline & Anemia & 6 \\
\hline & Trombocytopenia & 6 \\
\hline & Agammaglobulimia & 1 \\
\hline T cells (REP-TILs) & Dyspnea & 1 \\
\hline \multirow[t]{4}{*}{$I L-2$} & Performance status 3-4 & 3 \\
\hline & Fever & 3 \\
\hline & Fatigue & 2 \\
\hline & Vomiting & 1 \\
\hline \multirow{3}{*}{ Checkpoint inhibitors } & Colitis & 1 \\
\hline & Thyroiditis (grade 2) & 1 \\
\hline & Dry skin & 1 \\
\hline
\end{tabular}
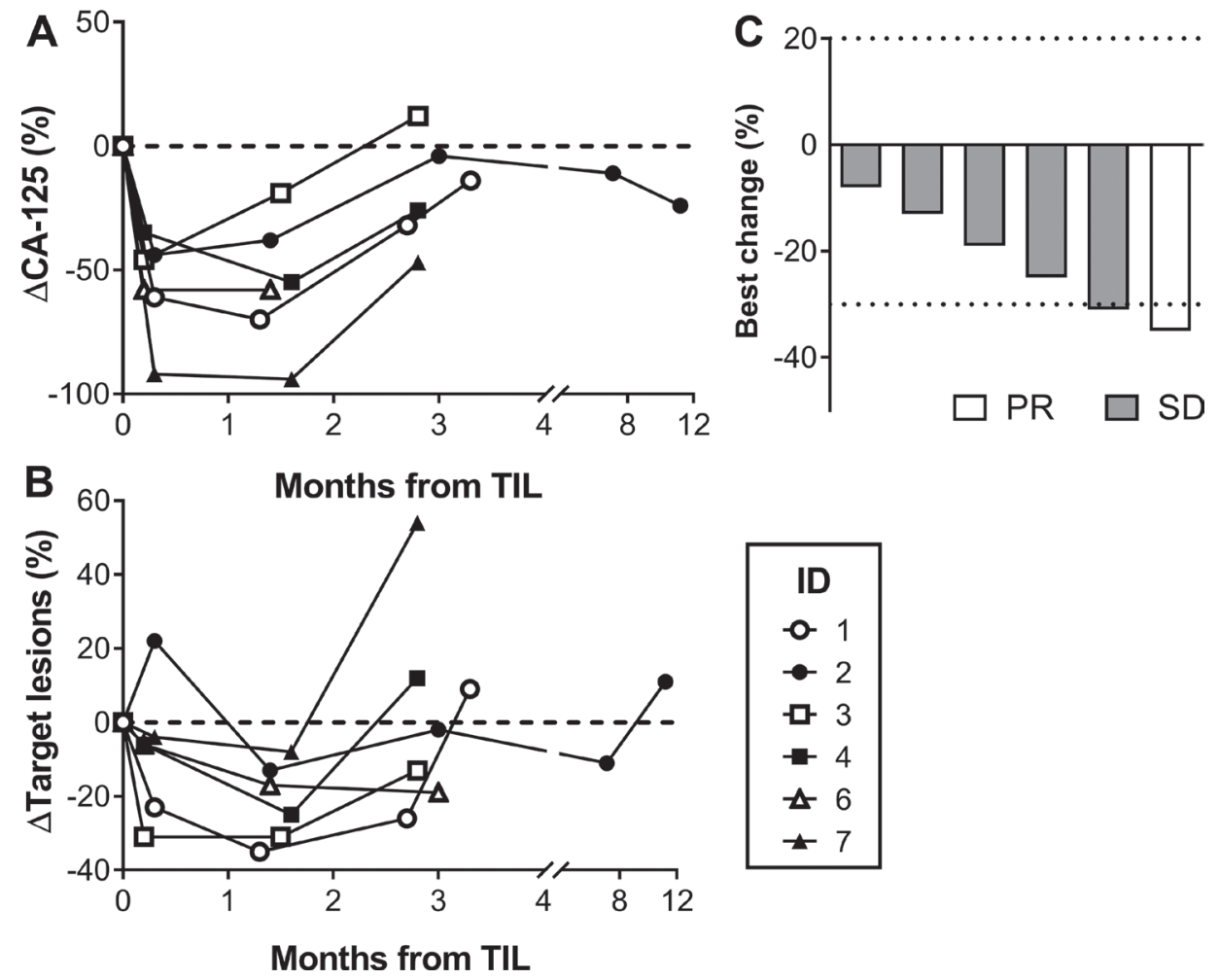

Figure 1: Clinical response. Clinical response curves following the infusion of ex vivo expanded TILs. (A) shows the proportional change of the cancer antigen-125 (CA-125) (B) shows radiological change in the target lesion sum according to RECIST 1.1, and (C) is a waterfall plot with the best overall response (BOR). 
medians of $37.1 \%$ (Range: $6.3-82.5 \%$ ) and $29.1 \%$ (Range: $3.9-62.3 \%$ ) of CD3+ cells respectively.

In contrast to our FACS data, we also found a considerable number of central memory (CM; CD45RA-, CCR7+) T cells with a median (of CD3+) of 7.4\% (range: $0.9-9.9 \%$ ) in CD4 T cells and 3\% (range: $0.4-19.6 \%$ ) in CD8. The other clusters were CD56+ T cells (NKTlike cells), median of $2.5 \%$ for CD4 (range: $0.6-18.3 \%$ ) and $8 \%$ for CD8 (range: $0.7-35.5 \%$ ), and a negligible number (medians $\leq 0.5 \%$ ) of gamma-delta $\mathrm{T}$ cells (TCRgd cells). All cells clustered expressed HLA-DR as a sign of profound activation. The Uniform Manifold Approximation and Projection (UMAP) and the clusters are shown in Figure 3 and listed in Supplementary Table 3, while the expression of non-lineage markers, heatmap and density plots are shown in Supplementary Figure 1 and 2.

\section{Tumor expression of selected immune markers}

Next, we investigated the tumor expression of, among others, the immune markers PD-L1, MHC

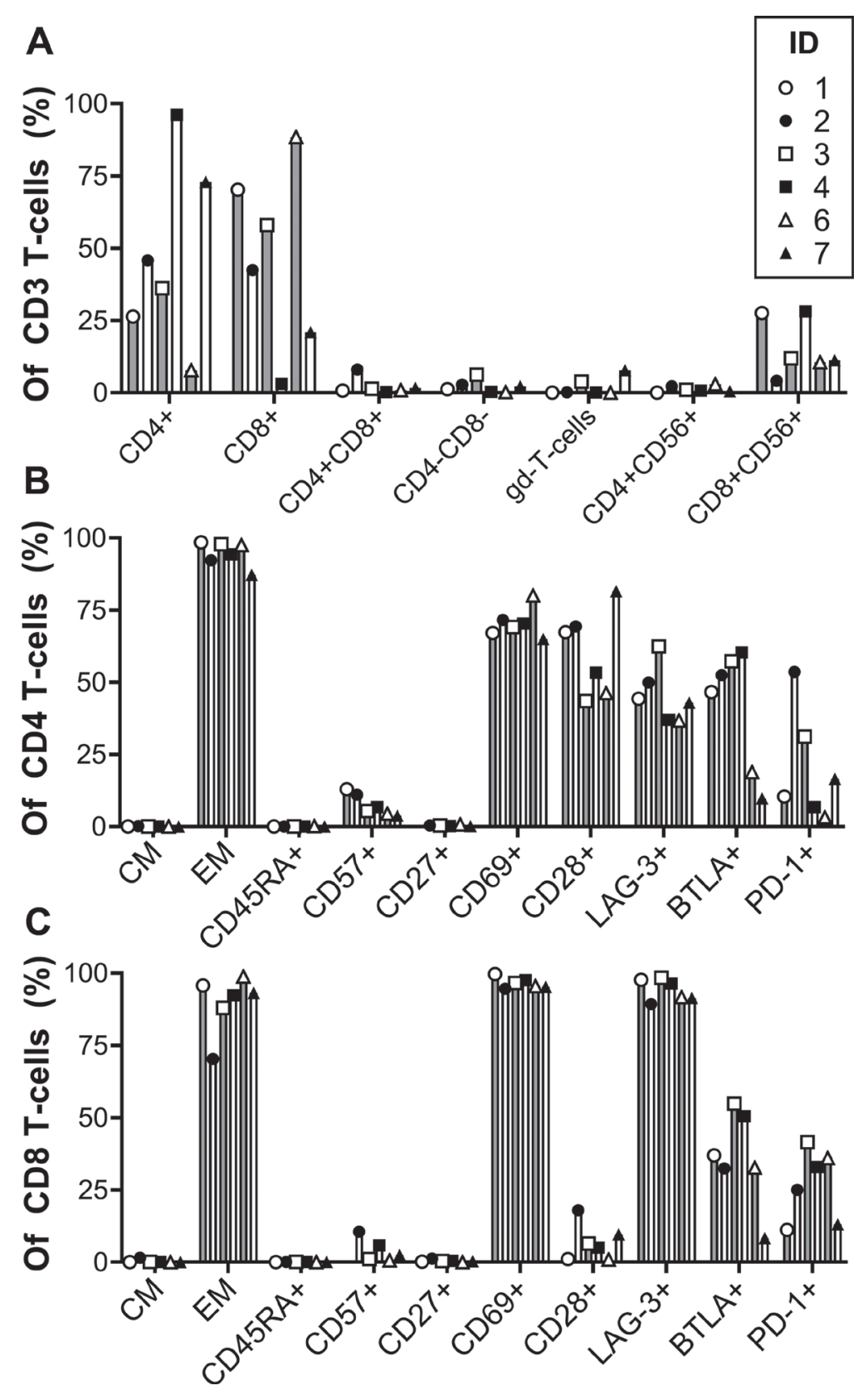

Figure 2: Phenotype of ex vivo expanded tumor infiltrating lymphocytes (REP-TILs). The combined flow cytometry results showing the different cell populations within the CD3+ T cells (A), CD4+ T cells (B) and CD8+ T cells (C). Gd: Gamma-delta; CM: Central memory (CD45RA-CCR7+); EM: Effector memory (CD45RA-CCR7-). 
class I and II. In 5 patients surplus tissue from the tumor resection was fixed and available for IHC and IF analysis. We found a high MHC I and II expression (>30 average count) in patient \#1, \#2 and \#3. Tumor expression of PD-L1 (CD163-PD-L1+; >25 average count) was found in patient \#1, \#2, \#3 and \#4. Examples of the IHC and IF analysis are shown in Figure 4. Interestingly, MHC class I and II expression were highly expressed in the 3 patients that achieved objective response, unconfirmed PR or sustained SD. The tumor expression of PD-L1, MHC class I and II was not significantly different from what was seen in our prior pilot study of patients without treatment with ipilimumab (data not shown).

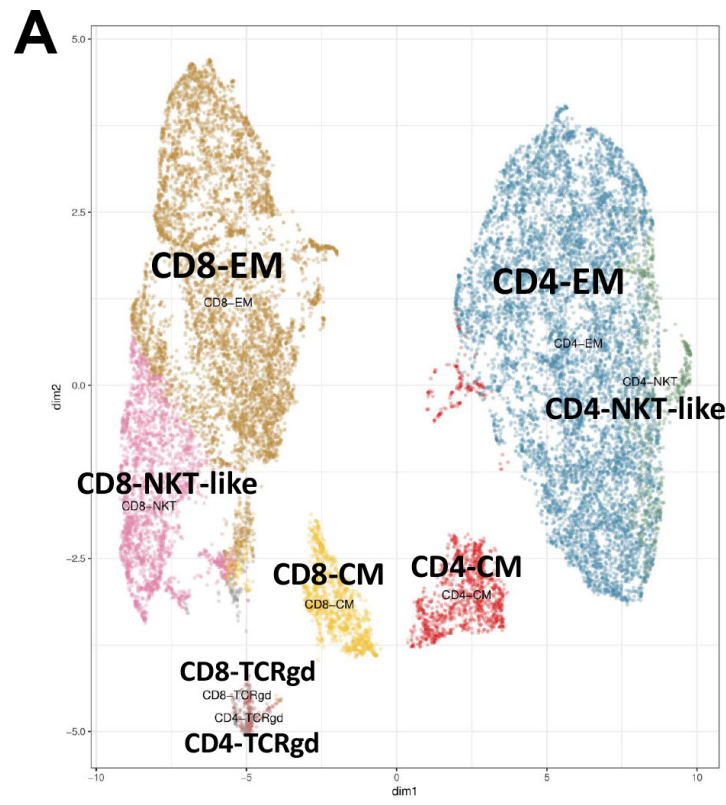

\section{TIL anti-tumor reactivity}

The in vitro tumor reactivity of the REP TILs was tested using autologous tumor cells. Tumor cells were either tumor cell culture (TC) or tumor digest (TD) established from the resected tumor tissue used for TIL expansion. Tumor samples were available from 5 patients. All patients had either CD4 or CD8 tumorreactive $\mathrm{T}$ cells. As shown in Figure 5, the highest reactivities were seen within the CD8 T cells, and the CD4 $\mathrm{T}$ cells were almost exclusively reactive against TD. Patient \#1,\#2, \#3 and \#4 showed CD4 anti-tumor reactivity, with respectively $21.1 \%, 8.2 \%, 2.3 \%$ and $3.8 \%$ positive cells, against TD. Patient \#1 and \#4

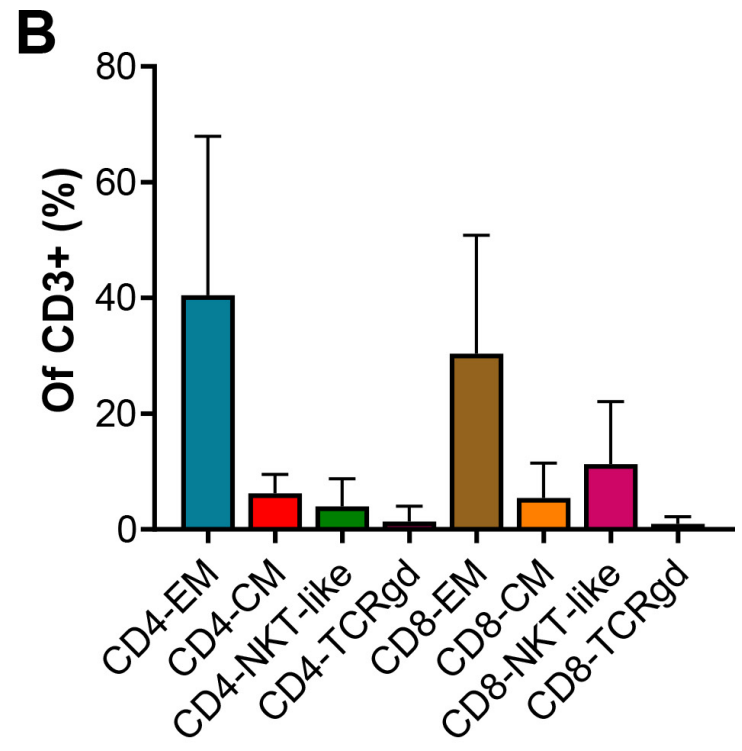

Figure 3: Mass cytometry of ex vivo expanded tumor infiltrating lymphocytes (REP-TILs). Semi-supervised clustering analysis based on CD4, CD8, CD45RO, CCR7, CD45RA, CD56, HLA-DR and TCRgd expression as lineage markers. (A) shows the Umap of the 8 resulting clusters while (B) shows the proportional size (median with range) of the clusters.
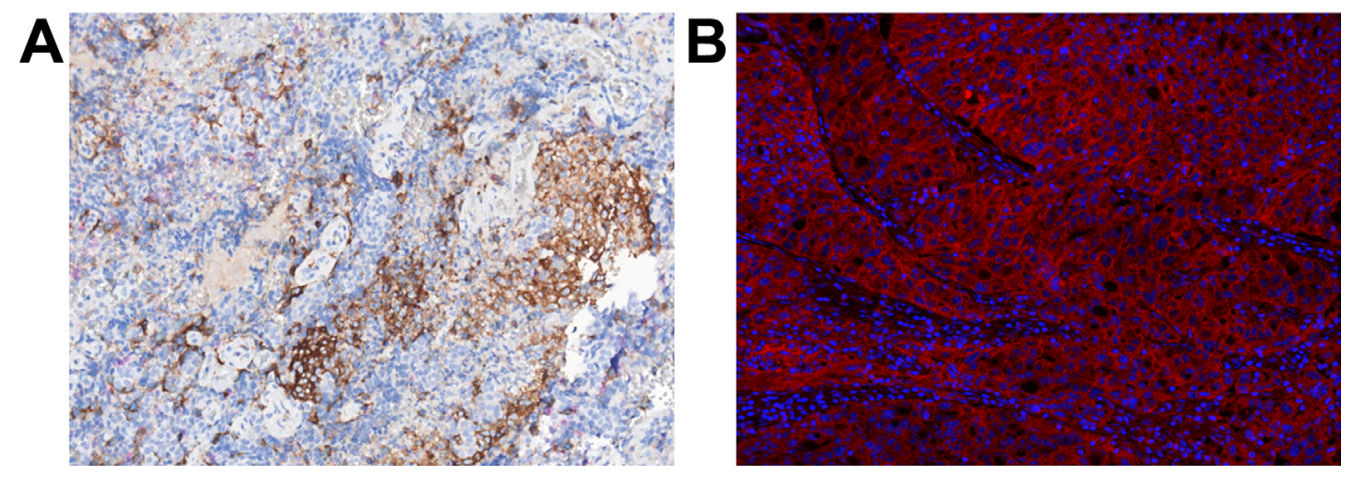

Figure 4: Immunohistochemistry and immunofluorescence of tumor tissue. (A) shows the PD-1/PD-L1/CD163/Hematoxylin staining of the tumor tissue from patient \#1, where PD-L1 is shown in brown, CD163 in blue, PD-1 in red and hematoxylin nuclear counterstain in dark blue. (B) is a component fluorescence image generated by inForm spectral unmixing, from the MHCI/MHCII/IDO/ DAPI staining, showing the MHC II class expression (in red) in the tumor tissue from patient \#3 and nuclear counterstain DAPI in blue. 
showed CD8 reactivity against TD and TC, patient \#3 only against TC treated with interferon-gamma (IFN), while patient $\# 7$ showed extensive reactivity against TC and TC-IFN with respectively $23.7 \%$ and $47.6 \%$ antitumor reactive $\mathrm{CD} 8$ cells.

\section{Influence of ipilimumab treatment on TIL expansion and function}

We compared the REP-TILs from the current patients with those from our previous pilot trial without ipilimumab treatment [18] to assess the influence of ipilimumab. The success rate of ex vivo T cell expansion was comparable and there was no significant difference in expansion time until REP. Though not significant, the median fold expansion was 4,235 in ipilimumab treated patients compared to 2,810 in the untreated leading to a higher number of infused $\mathrm{T}$ cells (median $84.7 \times 10 \mathrm{e} 9$ cells compared to $56.2 \times 10 \mathrm{e} 9$ cells $)$ in ipilimumab treated patients. In the ipilimumab treated patients, the median CD8 $\mathrm{T}$ cell content in the final TIL product was $50.2 \%$ vs. $25 \%$ (n. s.) in untreated patients and a CD4 $\mathrm{T}$ cell content of $41 \%$ vs. $64.8 \%$ (n. s.) respectively, resulting in median CD8: CD4 ratios of 1.3 vs. 0.5 (n. s.). The immune phenotype was slightly altered in ipilimumab treated patients with lower LAG-3 $(p=0.002)$ in the CD4 T cells and lower CD27 ( $p=0.002), \mathrm{CD} 28(p=0.015)$ and BTLA $(p=0.015)$ expression in the CD8 T cells. The phenotype comparison is shown in Supplementary Figure 3. The mass cytometry did not show significant differences between the clusters of ipilimumab treated and not treated patients. The sizes of the different clusters are listed in Supplementary Table 3. Antitumor reactivity of REP-TILs was found in 6 out of 6 of the ipilimumab treated patients compared to 4 out of 6 in patients not treated with ipilimumab and with a generally higher level of CD8 reactivity in ipilimumab treated patients $(p=0.048)$ with a pooled median of $0.8 \%$ (range: $0.1-$ $47.6 \%$ ) vs. $0.3 \%$ (range $0.1-1.6 \%$ ).

\section{DISCUSSION}

This study was established to examine the feasibility and potential benefit of adding ICI at specific time points during TIL ACT in ovarian cancer. We demonstrate that the investigated combination of checkpoint inhibition and ACT is a safe and feasible approach for immune therapy. Importantly, indication of clinical activity was seen with regression of target tumor lesions in all patients and two patients achieving a partial response (one unconfirmed). In addition, one patient achieved prolonged disease stabilization for almost a year. In the remaining patients the tumor responses were short-lived. It cannot be ruled out that clinical responses were partly or mainly induced by the supportive therapy with chemotherapy, ICI and/ or low dose IL-2. However, in our previous ACT trial in ovarian cancer with the same chemotherapy schedule, and high dose IL-2 (decrescendo) but without checkpoint inhibition, no patients achieved objective response despite being less heavily pretreated [18]. Thus, even though short-lived responses could be associated with chemotherapy, we would not expect the chemotherapy to elicit significant anti-neoplastic effects in these latestage ovarian cancer patients who all have progressed on several previous lines of chemotherapy. In this situation, it is also reasonable to assume that their disease would be very difficult to treat even with another, and otherwise promising, new therapy.

The treatment-related toxicity was manageable and largely comparable with our previous ACT studies besides the emergence of immune-related adverse
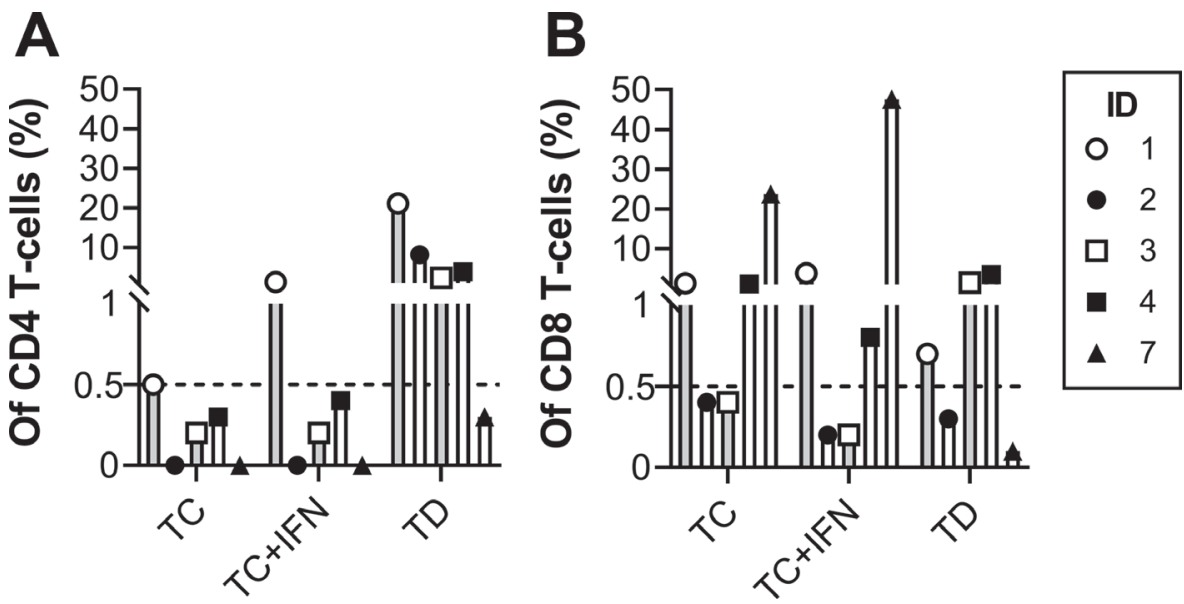

Figure 5: In vitro tumor reactivity of expanded TILs. Proportional number of reactive CD4 (A) and CD8 (B) T cells after 4 hours of co-culture with either cultured tumor cells (TC), cultured tumor cells with IFN-gamma (TC+IFN) or tumor digest (TD). Tumor reactivity was defined as the production of TNF and/or IFN-gamma and/or expression of CD107 as assessed by flow cytometry with $>0.5 \%$ tumor reactive $T$ cells and $>50$ events. 
events in two of the patients. These are anticipated with the use of checkpoint inhibitors [19]. Regarding lymphodepletion after preconditioning ipilimumab no specific disadvantages were observed. Thus, all patients reconstituted their immune system with a median time of neutropenia of 5.5 days which is less than melanoma patients without pretreatment with ipilimumab but with high dosis IL-2 $[28,29]$, and less than our previous trial in ovarian cancer patients, also with high dose IL-2, where the median time of neutropenia was 9 days (range: 8-10) [18]. One patient acquired a prolonged secondary B-cell deficiency (agammaglobulimia) that was attributed to the lymphodepleting chemotherapy [30].

Only half of the REP-TILs were CD8 dominated, and both patients with objective responses were treated with CD8 dominated REP-TILs. CD8 T cells are generally associated with anti-tumor immunity, and earlier data in melanoma indicate that the CD8 numbers correlate to better responses in ACT [31]. However, as our in vitro data show, both CD4 and CD8 can mediate anti-tumor-reactivity, which is also in line with earlier findings $[17,32,33]$. To this end, the patient with PR after therapy had anti-tumor reactivity in $21.1 \%$ CD4 REP-TILs and the patient with prolonged $\mathrm{SD}$ for almost a year was treated with a CD4 dominated TIL product with anti-tumor reactivity in $8.2 \%$ of CD4 REPTILs, while both showed modest CD8 anti-tumor reactivity.

The immune phenotyping of the REP-TILs showed that they were primarily effector memory (EM) T cells with an activated and differentiated phenotype. There were some exceptions such as the high CD28 expression on CD4 T cells and the general lack of CD57. In ACT of melanoma patients, data from our center (unpublished) and others have shown that high CD28 expression is a positive predictor of in vivo activity in TIL-based ACT [25]. The appearance of a CM T cell subset in the mass cytometry data is most likely due to the difference in method, including a different anti-CCR7 clone, and automated clustering analysis.

Similar to our previous study [18], we found a considerable expression of the immune checkpoints LAG-3, BTLA and PD-1. The PD-1 expression led us to add an anti-PD1 antibody to the ACT in the current trial. LAG-3 and BTLA are expressed on activated lymphocytes [21]. LAG-3 works primarily through binding of its ligand MHC class II [34] and is, together with PD-1, an important regulator of TILs in ovarian cancer [35]. MHC class I and II expression were found in several patients and coincided with favorable clinical responses. On the other hand, the co-expression of MHC class II on tumor cells and LAG-3 on CD8 REP-TILs is a potential limitation for the anti-tumor reactivity of REP-TILs and suggests that the addition of an anti-LAG-3 blocking antibody might be beneficial in these patients. Similarly, the importance of BTLA in the microenvironment of ovarian cancer has recently been reported [36] and, though the immune regulatory pathway might be more complex, anti-BTLA therapy might also be beneficial in ACT [37]. Still, two patients showed no tumor expression of MHC class I or II which could limit the tumor recognition and $\mathrm{T}$ cell reactivity altogether.

Patient preconditioning with the anti-CTLA-4 antibody ipilimumab was employed to increase tumor infiltration of tumor reactive lymphocytes before tumor tissue harvest for TIL production. To address the potentially beneficial effect of ipilimumab we compared TIL data from the present pilot study with data from our previous ovarian cancer pilot study without ipilimumab. Due to the low number of patients and the fact that they were separate clinical trials, we were not able to draw firm conclusions, however, data indicated several important potential beneficial effects including increased success rate of ex vivo TIL expansion and an improved quality of the TIL product comprising increased total TIL numbers, a more favorable CD8: CD4 ratio, and increased antitumor reactivity. Other studies indicate a similar influence of ipilimumab therapy on TILs [38, 39](Friese et al., Scientific Reports, in press). On the other hand, our data show that ipilimumab treatment seems to lower CD27 and $\mathrm{CD} 28$ expression on $\mathrm{CD} 8 \mathrm{~T}$ cells, while decreasing BTLA expression on CD8 T cells and LAG-3 on CD4 T cells, which indicates that ipilimumab results in REP TILs that are more differentiated, but with lower expression of immunological checkpoints. A comprehensive study of differences in TME dependent on pre-conditioning ipilimumab in these patients, including multiplex and nanostring analyses are subject of a separate study (Westergaard et al. Manuscript in preparation)

ACT for ovarian cancer is still in its cradle compared to malignant melanoma that is presently in phase III clinical testing (NCT02278887). However, accumulative evidence points towards a potential role of immunotherapy in ovarian cancer but with a modest efficacy of established ICIs. Thus, combination immunotherapy might be a way forward supporting a continuous development and refinement of ACT therapy for this purpose.

\section{MATERIALS AND METHODS}

\section{Study design}

TIL therapy was combined with checkpoint inhibition in a sequenced manner. The patients received one dose of ipilimumab ( $3 \mathrm{mg} / \mathrm{kg}) 2$ weeks prior to tumor resection for ex vivo TIL expansion. When the expanded cells reached sufficient numbers $(>20 \times 10 \mathrm{e} 6$ cells $)$, they were transferred to a rapid expansion protocol (REP) and the patients were admitted for therapy with conditioning chemotherapy, T cell infusion, nivolumab ( $3 \mathrm{mg} / \mathrm{kg}$; $\mathrm{q} 2 \mathrm{w}$ $\times 4)$ and low-dose IL-2 (2 MIE s. c. daily for 2 weeks). The conditioning chemotherapy consisted of 2 days with cyclophosphamide $(60 \mathrm{mg} / \mathrm{kg})$ followed by 5 days with fludarabine phosphate $\left(25 \mathrm{mg} / \mathrm{m}^{\wedge} 2\right)$. The study design 
is illustrated in Figure 6. The patients were monitored daily and scored for adverse events (CTCAE v4.0) during hospitalization and before every new therapy.

The primary endpoints were safety and feasibility of the therapy regimen. Secondary endpoints were radiologic response evaluation (RECIST 1.1) and immune monitoring. Radiologic imaging was performed at approximately 2, 6 and 12 weeks following $\mathrm{T}$ cell infusion, thereafter every 3 months.

\section{Patients}

Patients were recruited and treated at Herlev Hospital, Copenhagen, Denmark. Eligible patients must have exhausted available standard therapy options and have tumor lesions available for both surgical removal and response evaluation. Other inclusion criteria include: Pathologic diagnosis with epithelial ovarian cancer, ECOG performance status of $0-1$, permissible organ function, absence of chronic infections and absence of brain metastases.

Oral and written informed consent was obtained from all patients in accordance with the declaration of Helsinki. The study was approved by the National Ethics Committee, the Danish Medicines Agency and the Danish Data Protection Agency before commencement. The clinical trial is registered at clinicaltrials. gov (NCT03287674) and EudraCT (2017-002179-24).

In a previous clinical trial, we treated 6 ovarian cancer patients with TIL therapy without checkpoint inhibitors [18]. Data and material from this study were included for comparative analyses to e. g. investigate the effect of the ipilimumab treatment on the expanded T cells.

\section{Ex vivo TIL expansion}

Resected tumor lesions were immediately transported from the department of surgery to a GMP facility at Herlev Hospital for further processing. The tumors were manually dissected into 48 fragments and cultured in two 24-well plates (Nunc, Roskilde, Denmark) with complete medium (CM) containing; RPMI (Invitrogen, Waltham, MA), 1\% penicillin and streptomycin, 0.5\% Fungizone (Bristol-Myers Squibb, New York, NY), 10\% Human serum (Sigma-Aldrich, St. Louis, MO) and 6000 U/mL IL-2 (Aldesleukin; Novartis, Basel, Switzerland). The CM was exchanged every 2-3 days until reaching approximately $50 \times 10$ e 6 cells, when the cells were either cryopreserved for later use or further expanded in a rapid expansion protocol (REP). In the REP $20 \times 10 \mathrm{e} 6$ cells, together with irradiated (40 Gy) allogeneic feeder cells at a 1:200 ratio, were cultured in 80/20 medium (80\% CM and 20\% AIM-V medium) supplemented with $30 \mathrm{ng} / \mathrm{mL}$ anti-CD3 antibody (OKT3; Miltenyi Biotech, Bergisch Gladbach, Germany) and IL-2 at a concentration of $6000 \mathrm{U} / \mathrm{mL}$. After 7 days, the cells were moved from a static expansion to the dynamic Wave ${ }^{\circledR}$ system (GE Healthcare, Chicago, IL). After another 7 days of culture, the cells (REP-TILs) were infused into the patient. The method is further elaborated elsewhere [40] and identical to our previous clinical trial in ovarian cancer.

\section{Immune characterization of expanded TIL with flow- and mass cytometry}

For flow cytometry, REP-TILs were thawed and rested overnight in CM. Approximately $15 \times 10 \mathrm{e} 6$

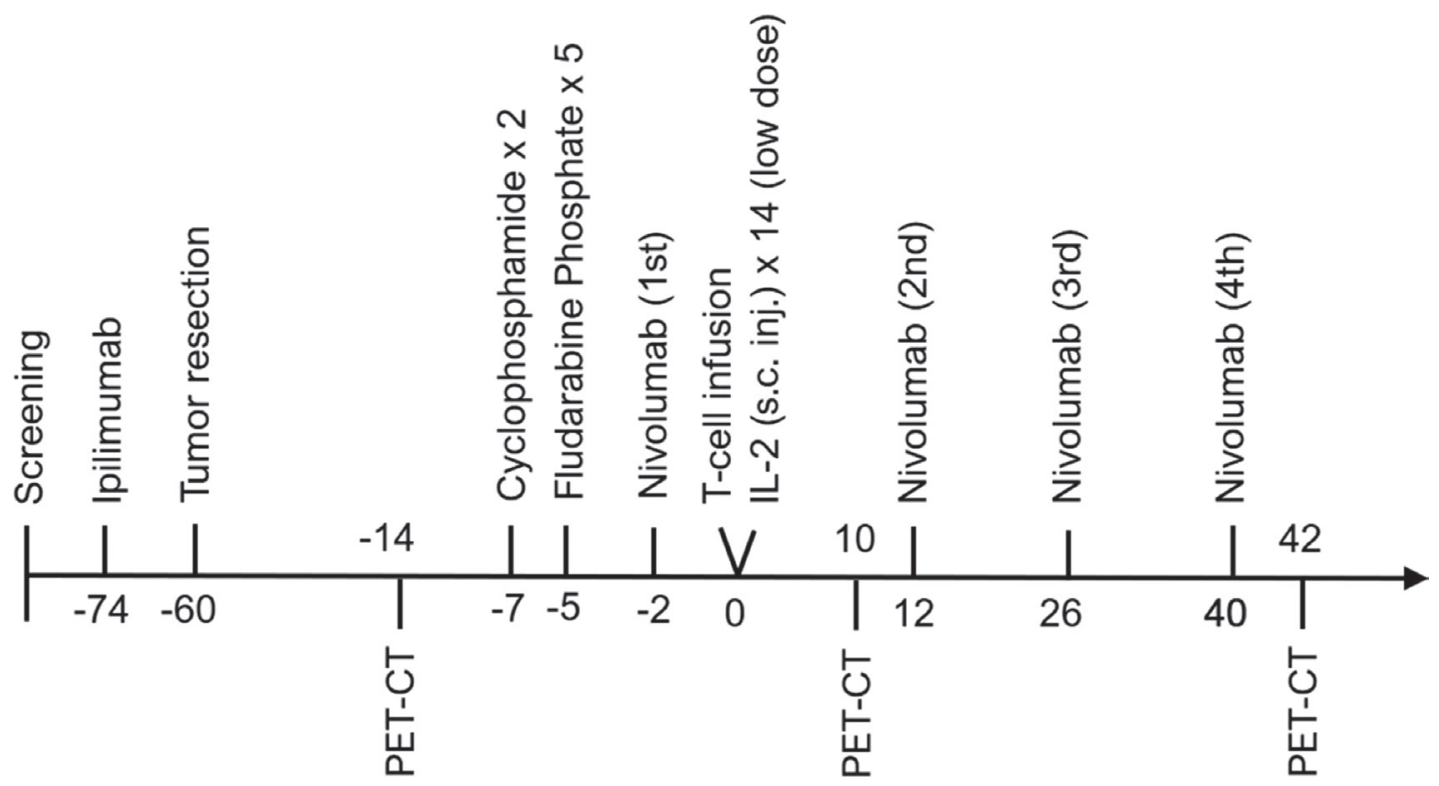

Figure 6: Therapy regimen. Overview and timeline of the trial with conditioning chemotherapy, adoptive cell therapy and checkpoint inhibitors during the clinical trial. 
cells were washed in phosphate-buffered saline and stained at $4^{\circ} \mathrm{C}$ for 30 minutes. The fluorochromelabeled monoclonal antibodies and panels are listed in Supplementary Table 1. The stained cells were analyzed on a FACS Canto II instrument (BD Biosciences).

Mass cytometry was performed at LUMC (Leiden, Netherlands). Approximately $2.5 \times 10 \mathrm{e} 6$ REP-TILs were stained with metal-labeled antibodies as described elsewhere [41]. The antibody panel is listed in Supplementary Table 2. Cells were first stained for $15 \mathrm{~min}$ with a live/dead identifier $1 \mathrm{mmol} / \mathrm{L}$ Cell-ID intercalator-103Rh (Fluidigm, San Francisco, CA) and washed with MaxPar Cell stain buffer (Fluidigm). The cells were incubated with Human TruStain FcX Fc Receptor Blocking Solution (Biolegend, San Diego, CA) for at least $10 \mathrm{~min}$ before staining with the metal-conjugated antibodies and incubated for $45 \mathrm{~min}$, followed by two washes with the MaxPar Cell stain buffer. The cells were stained overnight at $4^{\circ} \mathrm{C}$ with $125 \mathrm{nmol} / \mathrm{L}$ Cell-ID intercalator-Ir in MaxPar Fix and Perm Buffer (Fluidigm). The following day, the cells were washed and acquired by CyTOF 2 or helios-upgraded CyTOF 2 mass cytometer (Fluidigm). Data were then normalized by using EQ Four Element Calibration Beads (Fluidigm) with the reference EQ passport P13H2302.

Available REP TIL samples from our previous clinical trial in ovarian cancer patients [18] were analyzed with mass cytometry together while the flow cytometry was performed at different time points but with nearidentical antibody panels.

\section{Tumor immunohistochemistry and immunofluorescence}

Formalin-fixed paraffin-embedded (FFPE) tumor tissue samples were analyzed with multicolor IHC and immunofluorescence (IF) analysis. Methods and reagents are described in our previous TIL study [18]. All reagents were obtained from Biocare Medical (Pacheco, CA) unless otherwise listed. Slides were first deparaffinized through xylene and graded alcohols to water then subjected to antigen retrieval with Diva Decloaker.

HLA-I/HLA-II expression was analyzed with multicolor IF using OPAL reagents (Perkin Elmer, Waltham, MA). The manufacturer's instructions were followed. Briefly, HLA Class I A, B, C (clone EMR8-5, MBL, Woburn, MA) on OPAL520 was used in round 1, HLA-DP, DQ, DR (clone CR3/43, Affinity Bioreagents, Golden, CO) on OPAL650 in round 2 and IDO-1 (clone SP260, Spring Bioscience, San Francisco, CA) on OPAL570 in round 3. The staining with primary antibody was followed by staining with suitable MACH2 polymers (Biocare Medical).

To assess PD-L1/CD163 expression, a cocktail of anti-PD-L1 (clone SP142, Spring Bioscience, Pleasanton, CA) and anti-CD163 (clone 10D6, Biocare) in Da Vinci Green diluent was added for 30 minutes followed by MACH2 Double Stain \# 1 Polymer for 30 minutes. Before staining, Peroxidased-1 and then Background Sniper were added to block non-specific staining. The signal was detected by adding IP Ferangi blue followed by IP DAB. Slides were then subjected to denaturation at $50^{\circ} \mathrm{C}$ for 45 minutes in an SDS-glycine $\mathrm{pH} 2.0$ solution. Slides were then incubated with anti-PD1 (clone EPR4877 [2], Abcam) in Da Vinci Green diluent for 30 minutes followed by MACH2 Rabbit-AP Polymer for 30 minutes then IP Warp Red Chromogen. Slides were then counterstained with a 1:5 dilution of CAT hematoxylin, rinsed, air-dried and coverslipped with Ecomount.

\section{In vitro tumor reactivity}

When possible, tumor cell lines were established from the remaining transport medium after tumor fragmentation. The tumor cells were expanded in RPMI (Invitrogen), $1 \%$ penicillin and streptomycin, 0.5\% Fungizone (Bristol-Myers Squibb), 10\% FBS (Gibco, Nærum, Denmark). Some cell lines were additionally supplemented with insulin and sodium pyruvate. A tumor digest sample was prepared from tumor fragments that were enzymatically digested overnight using collagenase type IV (Sigma-Aldrich) and Pulmozyme (Roche, Basel, Switzerland) followed by cryopreservation.

REP TILs were tested for their ability to recognize either tumor digest or autologous cultured tumor cells with or without IFN-gamma stimulation. All antibodies were from BD bioscience unless otherwise listed. Briefly, TILs and tumor cells were co-cultured (3:1) for 5-7 hours in the presence of Golgi plug (BD biosciences) and CD107a-BV421. Cells were washed twice and stained with extracellular antibodies CD3-FITC, CD4-PerCP (Biolegend), CD8-Qdot605 (Invitrogen), CD56-PE, and Near-IR live-dead (Thermo Fisher, Waltham, MA) for 40 min followed by a wash. Fixation and permeabilization buffer (eBioscience, San Diego, CA) were added for overnight incubation at $4^{\circ} \mathrm{C}$. The next day, cells were washed in fixation buffer and stained with intracellular antibodies TNF-APC and IFN-gamma-PE-Cy7 for $40 \mathrm{~min}$. The cells were acquired on a FACS Canto II (BD biosciences). The method is described in more detail elsewhere [7].

\section{Data and statistical analysis}

T cell subsets from the FACS data were gated using Flowjo software (BD biosciences). Differential abundance of subsets was tested with Mann-Whitney $U$ test and $p$-values $<0.05$ were considered statistically significant.

The mass cytometry data was manually gated for single, live and CD45+ cells using the cloud-based Cytobank software (Fluidigm) and exported as FCS files. A multidimensional unsupervised clustering analysis [42] was done using the algorithm flowSOM [43] for R (R Foundation for Statistical Computing, Vienna, Austria) using CD4, CD8, CD45RA, CCR7, CD45RA, CD56, HLA-DR and TCRgd as lineage markers. Dimensionality 
reduction visualizations were generated using Uniform Manifold Approximation and Projection (UMAP) [44]. Statistical analysis of differential abundance of cell subsets was done with Negative Binomial Generalized Linear Model and $p$-values $>0.05$ after multiple testing correction using Benjamini Hochberg false discovery rate were considered statistically significant.

In the tumor reactivity analysis, tumor reactivity was defined as the production of TNF- $\alpha$ and/or IFN-gamma and/or expression of CD107a. REP-TILs without tumor stimulation were used as a negative control and subtracted from the tumor reactivity results. A positive anti-tumor response was defined as $>0.5 \%$ positive of CD4 or CD8 $\mathrm{T}$ cells with $>50$ events.

Vectra 2 Multispectral Imaging system (Perkin Elmer, Waltham, MA) was used for imaging of slides. Ten $20 \times$ images per slide that had at least $90 \%$ tissue content in the field of view were collected. InForm image analysis software (Perkin Elmer) was used for the cell phenotype analysis. For each panel, 5 algorithms were developed, and the results were visually validated to ensure accuracy. Significant differences were tested with Mann-Whitney $U$ test and $p$-values $>0.05$ were considered statistically significant.

\section{CONCLUSIONS}

In this pilot study, we demonstrate the anti-tumor reactivity potential of unselected REP-TILs in ovarian cancer patients. Our findings suggest that checkpoint inhibition is advantageous in this ACT setting in terms of TIL production and clinical efficacy.

\section{Author contributions}

Conception and design: Anders H. Kverneland, Magnus Pedersen, Marie Christine Wulff Westergaard, Troels Holz Borch, Inge Marie Svane; Provision of study materials or patients; Anders H. Kverneland, Magnus Pedersen, Morten Nielsen; Collection and assembly of data: Anders H. Kverneland, Magnus Pedersen, Marie Christine Wulff Westergaard, Saskia J.A.M. Santegoets: Data analysis and interpretation: Anders H. Kverneland, Marie Christine Wulff Westergaard, Saskia J.A.M. Santegoets, Sjoerd H. van der Burg, Brad Nelson, Lars Rønn, Gitte Aabjerg. Manuscript writing: Anders H. Kverneland, Inge Marie Svane; Final approval of manuscript. Anders Handrup Kverneland, Magnus Pedersen, Marie Christine Wulff Westergaard, Morten Nielsen, Troels Holz Borch, Lars Rønn, Saskia J.A.M. Santegoets, Sjoerd H. van der Burg, Brad Nelson, Özcan Met, Marco Donia, Inge Marie Svane.

\section{ACKNOWLEDGMENTS}

We would like to thank the laboratory technicians Susanne Wendt, Sandra Ullitz Færch and Betina Johansen for invaluable help with the clinical cell manufacturing; and the Department of Oncology, Herlev Hospital, physicians and nurses for their support in taking care of the patients with special thanks to project nurse Anne Kuld-Nielsen in this regard.

We would like to thank Vanessa J. van Ham from the Leiden University Medical Center (LUMC), who was instrumental in performing the mass cytometry analysis.

We would also like to thank Mia Kennedy, Gillian Briggs, Stacey Ledoux, SungMin Huh and Shelby Thornton from the Deeley Research Centre, BC Cancer in Victoria, Canada for their vital contribution to the immunohistochemistry and -flourescence results.

\section{CONFLICTS OF INTEREST}

The authors declare no conflicts of interest.

All patients have given oral and written consent to participate in the clinical trial.

\section{FUNDING}

This work was supported by the Danish Cancer Society, Aase and Einar Danielsen Foundation, the Anticancer Fund and Ovacure. This work was supported by Herlev Research Council, the Danish Cancer Society, Aase and Einar Danielsen Foundation, Ovacure and Terry Fox Research Institute (Canada).

\section{REFERENCES}

1. Zhang L, Conejo-Garcia JR, Katsaros D, Gimotty PA, Massobrio M, Regnani G, Makrigiannakis A, Gray H, Schlienger K, Liebman MN, Rubin SC, Coukos G. Intratumoral $\mathrm{T}$ cells, recurrence, and survival in epithelial ovarian cancer. N Engl J Med. 2003; 348:203-13. https:// doi.org/10.1056/NEJMoa020177. [PubMed]

2. Hwang WT, Adams SF, Tahirovic E, Hagemann IS, Coukos G. Prognostic significance of tumor-infiltrating T cells in ovarian cancer: a meta-analysis. Gynecol Oncol. 2012; 124:192-98. https://doi.org/10.1016/j.ygyno.2011.09.039. [PubMed]

3. Sato E, Olson SH, Ahn J, Bundy B, Nishikawa H, Qian F, Jungbluth AA, Frosina D, Gnjatic S, Ambrosone C, Kepner J, Odunsi T, Ritter G, et al. Intraepithelial CD8+ tumorinfiltrating lymphocytes and a high CD8+/regulatory $\mathrm{T}$ cell ratio are associated with favorable prognosis in ovarian cancer. Proc Natl Acad Sci U S A. 2005; 102:18538-43. https://doi.org/10.1073/pnas.0509182102. [PubMed]

4. Vogelstein B, Papadopoulos N, Velculescu VE, Zhou S, Diaz LA Jr, Kinzler KW. Human genome sequencing. Science. 2013; 339:1546-58. https://doi.org/10.1126/science.1235122. [PubMed]

5. Alexandrov LB, Nik-Zainal S, Wedge DC, Aparicio SA, Behjati S, Biankin AV, Bignell GR, Bolli N, Borg A, 
Børresen-Dale AL, Boyault S, Burkhardt B, Butler AP, et al, and Australian Pancreatic Cancer Genome Initiative, and ICGC Breast Cancer Consortium, and ICGC MMML-Seq Consortium, and ICGC PedBrain. Signatures of mutational processes in human cancer. Nature. 2013; 500:415-21. https://doi.org/10.1038/nature12477. [ubMed]

6. Rizvi NA, Hellmann MD, Snyder A, Kvistborg P, Makarov V, Havel JJ, Lee W, Yuan J, Wong P, Ho TS, Miller ML, Rekhtman N, Moreira AL, et al. Cancer immunology. Mutational landscape determines sensitivity to PD-1 blockade in non-small cell lung cancer. Science. 2015; 348:124-28. https://doi.org/10.1126/science.aaa1348. [PubMed]

7. Westergaard MC, Andersen R, Chong C, Kjeldsen JW, Pedersen M, Friese C, Hasselager T, Lajer H, Coukos G, Bassani-Sternberg M, Donia M, Svane IM. Tumour-reactive $\mathrm{T}$ cell subsets in the microenvironment of ovarian cancer. Br J Cancer. 2019; 120:424-34. https://doi.org/10.1038/ s41416-019-0384-y. [PubMed]

8. Bobisse S, Genolet R, Roberti A, Tanyi JL, Racle J, Stevenson BJ, Iseli C, Michel A, Le Bitoux MA, Guillaume P, Schmidt J, Bianchi V, Dangaj D, et al. Sensitive and frequent identification of high avidity neo-epitope specific CD8 + T cells in immunotherapy-naive ovarian cancer. Nat Commun. 2018; 9:1092. https://doi.org/10.1038/s41467018-03301-0. [PubMed]

9. Hamanishi J, Mandai M, Ikeda T, Minami M, Kawaguchi A, Murayama T, Kanai M, Mori Y, Matsumoto S, Chikuma S, Matsumura N, Abiko K, Baba T, et al. Safety and antitumor activity of Anti-PD-1 antibody, nivolumab, in patients with platinum-resistant ovarian cancer. J Clin Oncol. 2015; 33:4015-22. https://doi.org/10.1200/JCO.2015.62.3397. [PubMed]

10. Matulonis UA, Shapira-Frommer R, Santin AD, Lisyanskaya AS, Pignata S, Vergote I, Raspagliesi F, Sonke GS, Birrer M, Provencher DM, Sehouli J, Colombo N, González-Martín A, et al. Antitumor activity and safety of pembrolizumab in patients with advanced recurrent ovarian cancer: results from the phase II KEYNOTE-100 study. Ann Oncol. 2019; 30:1080-87. https://doi.org/10.1093/annonc/ mdz135. [PubMed]

11. Schachter J, Ribas A, Long GV, Arance A, Grob JJ, Mortier L, Daud A, Carlino MS, McNeil C, Lotem M, Larkin J, Lorigan P, Neyns B, et al. Pembrolizumab versus ipilimumab for advanced melanoma: final overall survival results of a multicentre, randomised, open-label phase 3 study (KEYNOTE-006). Lancet. 2017; 390:1853-62. https://doi.org/10.1016/S0140-6736(17)31601-X. [PubMed]

12. Garon EB, Rizvi NA, Hui R, Leighl N, Balmanoukian AS, Eder JP, Patnaik A, Aggarwal C, Gubens M, Horn L, Carcereny E, Ahn MJ, Felip E, et al, and KEYNOTE-001 Investigators. Pembrolizumab for the treatment of nonsmall-cell lung cancer. N Engl J Med. 2015; 372:2018-28. https://doi.org/10.1056/NEJMoa1501824. [PubMed]

13. Kato K, Cho BC, Takahashi M, Okada M, Lin CY, Chin K, Kadowaki S, Ahn MJ, Hamamoto Y, Doki Y, Yen CC,
Kubota Y, Kim SB, et al. Nivolumab versus chemotherapy in patients with advanced oesophageal squamous cell carcinoma refractory or intolerant to previous chemotherapy (ATTRACTION-3): a multicentre, randomised, open-label, phase 3 trial. Lancet Oncol. 2019; 20:1506-17. https://doi. org/10.1016/S1470-2045(19)30626-6. [PubMed]

14. Fujita K, Ikarashi H, Takakuwa K, Kodama S, Tokunaga A, Takahashi T, Tanaka K. Prolonged disease-free period in patients with advanced epithelial ovarian cancer after adoptive transfer of tumor-infiltrating lymphocytes. Clin Cancer Res. 1995; 1:501-07. [PubMed]

15. Aoki Y, Takakuwa K, Kodama S, Tanaka K, Takahashi M, Tokunaga A, Takahashi T. Use of adoptive transfer of tumor-infiltrating lymphocytes alone or in combination with cisplatin-containing chemotherapy in patients with epithelial ovarian cancer. Cancer Res. 1991; 51:1934-39. [PubMed]

16. Zacharakis N, Chinnasamy H, Black M, Xu H, Lu YC, Zheng Z, Pasetto A, Langhan M, Shelton T, Prickett T, Gartner J, Jia L, Trebska-McGowan K, et al. Immune recognition of somatic mutations leading to complete durable regression in metastatic breast cancer. Nat Med. 2018; 24:724-30. https:// doi.org/10.1038/s41591-018-0040-8. [PubMed]

17. Tran E, Turcotte S, Gros A, Robbins PF, Lu YC, Dudley ME, Wunderlich JR, Somerville RP, Hogan K, Hinrichs CS, Parkhurst MR, Yang JC, Rosenberg SA. Cancer immunotherapy based on mutation-specific CD4+ T cells in a patient with epithelial cancer. Science. 2014; 344:641-45. https://doi.org/10.1126/science.1251102. [PubMed]

18. Pedersen M, Westergaard MC, Milne K, Nielsen M, Borch TH, Poulsen LG, Hendel HW, Kennedy M, Briggs G, Ledoux S, Nøttrup TJ, Andersen P, Hasselager T, et al. Adoptive cell therapy with tumor-infiltrating lymphocytes in patients with metastatic ovarian cancer: a pilot study. Oncoimmunology. 2018; 7:e1502905. https://doi.org/10.1 080/2162402X.2018.1502905. [PubMed]

19. Larkin J, Chiarion-Sileni V, Gonzalez R, Grob JJ, Cowey CL, Lao CD, Schadendorf D, Dummer R, Smylie M, Rutkowski P, Ferrucci PF, Hill A, Wagstaff J, et al. Combined Nivolumab and Ipilimumab or Monotherapy in Previously Untreated Melanoma Corresponding authors. N Engl J Med. 2015; 373:23-34. https://doi.org/10.1056/NEJMoa1504030. [PubMed]

20. Krummel MF, Allison JP. CD28 and CTLA-4 have opposing effects on the response of T cells to stimulation. J Exp Med. 1995; 182:459-65. https://doi.org/10.1084/jem.182.2.459. [PubMed]

21. Pardoll DM. The blockade of immune checkpoints in cancer immunotherapy. Nat Rev Cancer. 2012; 12:252-64. https:// doi.org/10.1038/nrc3239. [PubMed]

22. Curran MA, Montalvo W, Yagita H, Allison JP. PD-1 and CTLA-4 combination blockade expands infiltrating $\mathrm{T}$ cells and reduces regulatory $\mathrm{T}$ and myeloid cells within B16 melanoma tumors. Proc Natl Acad Sci U S A. 2010; 107:4275-80. https://doi.org/10.1073/pnas.0915174107. [PubMed] 
23. Wei SC, Levine JH, Cogdill AP, Zhao Y, Anang NA, Andrews MC, Sharma P, Wang J, Wargo JA, Pe'er D, Allison JP. Distinct Cellular Mechanisms Underlie AntiCTLA-4 and Anti-PD-1 Checkpoint Blockade. Cell. 2017; 170:1120-1133.e17. https://doi.org/10.1016/j. cell.2017.07.024. [PubMed]

24. Kodumudi KN, Siegel J, Weber AM, Scott E, Sarnaik AA, Pilon-Thomas S. Immune checkpoint blockade to improve tumor infiltrating lymphocytes for adoptive cell therapy. PLoS One. 2016; 11:e0153053. https://doi.org/10.1371/ journal.pone.0153053. [PubMed]

25. Rosenberg SA, Yang JC, Sherry RM, Kammula US, Hughes MS, Phan GQ, Citrin DE, Restifo NP, Robbins PF, Wunderlich JR, Morton KE, Laurencot CM, Steinberg $\mathrm{SM}$, et al. Durable complete responses in heavily pretreated patients with metastatic melanoma using T-cell transfer immunotherapy. Clin Cancer Res. 2011; 17:4550-57. https://doi.org/10.1158/1078-0432.CCR-11-0116. [PubMed]

26. Ellebaek E, Iversen TZ, Junker N, Donia M, EngellNoerregaard L, Met Ö, Hölmich LR, Andersen RS, Hadrup $\mathrm{SR}$, Andersen MH, thor Straten P, Svane IM. Adoptive cell therapy with autologous tumor infiltrating lymphocytes and low-dose Interleukin-2 in metastatic melanoma patients. J Transl Med. 2012; 10:169. https://doi.org/10.1186/14795876-10-169. [PubMed]

27. Donia M, Andersen R, Ellebaek E, Iversen TZ, Andersen $\mathrm{MH}$, Per thor StratenInge Marie Svane. Adoptive T-cell therapy (ACT) with TILs for metastatic melanoma: clinical responses and durable persistence of anticancer responses in peripheral blood. J Clin Oncol. 2013; 31:31. https://doi. org/10.1200/jco.2013.31.15 suppl.3028.

28. Andersen R, Donia M, Ellebaek E, Borch TH, Kongsted P, Iversen TZ, Hölmich LR, Hendel HW, Met Ö, Andersen MH, Thor Straten P, Svane IM. Long-Lasting complete responses in patients with metastatic melanoma after adoptive cell therapy with tumor-infiltrating lymphocytes and an attenuated il2 regimen. Clin Cancer Res. 2016; 22:3734-45. https://doi.org/10.1158/1078-0432.CCR-151879. [PubMed]

29. Dudley ME, Wunderlich JR, Yang JC, Hwu P, Schwartzentruber DJ, Topalian SL, Sherry RM, Marincola FM, Leitman SF, Seipp CA, Rogers-Freezer L, Morton KE, Nahvi A, et al. A phase I study of nonmyeloablative chemotherapy and adoptive transfer of autologous tumor antigen-specific $\mathrm{T}$ lymphocytes in patients with metastatic melanoma. J Immunother. 2002; 25:243-51. https://doi. org/10.1097/00002371-200205000-00007. [PubMed]

30. Venhoff N, Effelsberg NM, Salzer U, Warnatz K, Peter HH, Lebrecht D, Schlesier M, Voll RE, Thiel J. Impact of rituximab on immunoglobulin concentrations and $\mathrm{B}$ cell numbers after cyclophosphamide treatment in patients with ANCA-associated vasculitides. PLoS One. 2012; 7:e37626. https://doi.org/10.1371/journal.pone.0037626. [PubMed]
31. Besser MJ, Shapira-Frommer R, Itzhaki O, Treves AJ, Zippel DB, Levy D, Kubi A, Shoshani N, Zikich D, Ohayon Y, Ohayon D, Shalmon B, Markel G, et al. Adoptive transfer of tumor-infiltrating lymphocytes in patients with metastatic melanoma: intent-to-treat analysis and efficacy after failure to prior immunotherapies. Clin Cancer Res. 2013; 19:4792-800. https://doi.org/10.1158/1078-0432.CCR-13-0380. [PubMed]

32. Linnemann $C$, van Buuren MM, Bies L, Verdegaal EM, Schotte R, Calis JJ, Behjati S, Velds A, Hilkmann H, Atmioui DE, Visser M, Stratton MR, Haanen JB, et al. Highthroughput epitope discovery reveals frequent recognition of neo-antigens by CD4+ T cells in human melanoma. Nat Med. 2015; 21:81-85. https://doi.org/10.1038/nm.3773. [PubMed]

33. Friedman KM, Prieto PA, Devillier LE, Gross CA, Yang JC, Wunderlich JR, Rosenberg SA, Dudley ME. Tumorspecific CD4+ melanoma tumor-infiltrating lymphocytes. J Immunother. 2012; 35:400-08. https://doi.org/10.1097/ CJ.0b013e31825898c5. [PubMed]

34. Huard B, Mastrangeli R, Prigent P, Bruniquel D, Donini S, El-Tayar N, Maigret B, Dréano M, Triebel F. Characterization of the major histocompatibility complex class II binding site on LAG-3 protein. Proc Natl Acad Sci U S A. 1997; 94:5744-49. https://doi.org/10.1073/ pnas.94.11.5744. [PubMed]

35. Matsuzaki J, Gnjatic S, Mhawech-Fauceglia P, Beck A, Miller A, Tsuji T, Eppolito C, Qian F, Lele S, Shrikant P, Old LJ, Odunsi K. Tumor-infiltrating NY-ESO-1-specific CD8+ T cells are negatively regulated by LAG-3 and PD-1 in human ovarian cancer. Proc Natl Acad Sci U S A. 2010; 107:7875-80. https://doi.org/10.1073/pnas.1003345107. [PubMed]

36. Chen YL, Lin HW, Chien CL, Lai YL, Sun WZ, Chen CA, Cheng WF. BTLA blockade enhances Cancer therapy by inhibiting IL-6/IL-10-induced CD19high B lymphocytes. J Immunother Cancer. 2019; 7:313. https://doi.org/10.1186/ s40425-019-0744-4. [PubMed]

37. Fourcade J, Sun Z, Pagliano O, Guillaume P, Luescher IF, Sander C, Kirkwood JM, Olive D, Kuchroo V, Zarour HM. CD8(+) T cells specific for tumor antigens can be rendered dysfunctional by the tumor microenvironment through upregulation of the inhibitory receptors BTLA and PD-1. Cancer Res. 2012; 72:887-96. https://doi.org/10.1158/00085472.CAN-11-2637. [PubMed]

38. Bjoern J, Lyngaa R, Andersen R, Hölmich LR, Hadrup SR, Donia M, Svane IM. Influence of ipilimumab on expanded tumour derived $\mathrm{T}$ cells from patients with metastatic melanoma. Oncotarget. 2017; 8:27062-74. https://doi. org/10.18632/oncotarget.16003. [PubMed]

39. Mullinax JE, Hall M, Prabhakaran S, Weber J, Khushalani N, Eroglu Z, Brohl AS, Markowitz J, Royster E, Richards A, Stark V, Zager JS, Kelley L, et al. Combination of Ipilimumab and Adoptive Cell Therapy with TumorInfiltrating Lymphocytes for Patients with Metastatic Melanoma. Front Oncol. 2018; 8:44. https://doi. org/10.3389/fonc.2018.00044. [PubMed] 
40. Donia M, Larsen SM, Met O, Svane IM. Simplified protocol for clinical-grade tumor-infiltrating lymphocyte manufacturing with use of the Wave bioreactor. Cytotherapy. 2014; 16:1117-20. https://doi.org/10.1016/j. jeyt.2014.02.004. [PubMed]

41. Santegoets SJ, van Ham VJ, Ehsan I, Charoentong P, Duurland CL, van Unen V, Höllt T, van der Velden LA, van Egmond SL, Kortekaas KE, de Vos van Steenwijk PJ, van Poelgeest MI, Welters MJ, van der Burg SH. The Anatomical Location Shapes the Immune Infiltrate in Tumors of Same Etiology and Affects Survival. Clin Cancer Res. 2019; 25:240-52. https://doi.org/10.1158/1078-0432. CCR-18-1749. [ [PubMed]
42. Pedersen $\mathrm{CB}$, Olsen LR. Algorithmic Clustering Of Single-Cell Cytometry Data-How Unsupervised Are These Analyses Really? Cytometry A. 2020; 97:219-21. https:// doi.org/10.1002/cyto.a.23917. [PubMed]

43. Van Gassen S, Callebaut B, Van Helden MJ, Lambrecht BN, Demeester P, Dhaene T, Saeys Y. FlowSOM: using self-organizing maps for visualization and interpretation of cytometry data. Cytometry A. 2015; 87:636-45. https://doi. org/10.1002/cyto.a.22625. [PubMed]

44. McInnes L, Healy J, Melville J. UMAP: Uniform Manifold Approximation and Projection for Dimension Reduction. 2018 Feb 9. Available from: http://arxiv.org/ abs/1802.03426. 